Jurnal Bisnis dan Manajemen, Volume 21, No. 2, September 2020, p. 88-99

\title{
LOCATION-BASED ADVERTISING: INTRUSIVENESS AND IRRITATION
}

\author{
Senny Handayani Suarsa ${ }^{1}$ \\ Politeknik Pos, Indonesia
}

\begin{abstract}
Location-based Advertising (LBA) is a marketing strategy using cellular devices such as smartphones to offer products to potential customers at the nearest sales or service location. Intrusiveness and irritation are disorders that appear in the LBA. The conceptual framework of the research is built on the Advertising Avoidance Theory. Data collection was carried out with a self-administered survey involving 356 Politeknik Pos Indonesia students. The results showed that Intrusiveness and Irritation had a positive and significant effect on consumer attitudes toward LBA messages. Meanwhile, Intrusiveness has a negative and significant impact on consumer purchase intention, while irritation has a positive and significant impact on purchase intention. The more positive consumer attitudes towards LBA, the more positive the consumer's intention to buy.
\end{abstract}

Keywords: location-based advertising, intrusiveness, irritation, attitude to advertising, purchase intention

\section{LOCATION-BASED ADVERTISING: INTRUSIVE DAN IRITASI}

\begin{abstract}
Abstrak
Location-based Advertising (LBA) adalah strategi pemasaran dengan menggunakan perangkat seluler seperti smartphone untuk menawarkan produk kepada pelanggan potensial di lokasi penjualan atau layanan terdekat. Intrussiveness dan irritation merupakan gangguan-gangguan yang muncul dalam LBA. Kerangka konseptual penelitian dibangun berdasarkan Advertising Avoidance Theory. Dimana pengumpulan data dilakukan dengan self-administered survey dengan melibatkan 356 mahasiswa Politeknik Pos Indonesia. Hasil penelitian menunjukkan bahwa Intrusiveness dan Irritation berpengaruh secara positif dan signifikan terhadap sikap konsumen terhadap pesan LBA. Sementara itu Intrusiveness memberikan dampak yang negatif dan signifikan terhadap minat membeli konsumen, dan irritation memberikan dampak positif dan signifikan terhadap minat membeli. Begitu pula semakin positif sikap konsumen pada LBA, semakin positif pula niat konsumen untuk membeli.
\end{abstract}

Kata-kata Kunci: Location-Based Advertising, intrusiveness, irritation, sikap terhdap iklan, niat beli

\footnotetext{
${ }^{1}$ Korespondensi: Senny Handayani Suarsa, SE., MM. Politeknik Pos Indonesia. Jln. Sariasih No.54, Sarijadi, Sukasari, Kota Bandung, Jawa Barat 40151. Email: sennyhandayani@upi.edu
} 
Jurnal Bisnis dan Manajemen, Volume 21, No. 2, September 2020, p. 88-99

\section{INTRODUCTION}

Indonesia is one of the countries with the largest number of internet users in the world. Based on the Indonesian Internet Service Providers Association
(APJII) in 2017, the number of internet users in Indonesia reached 143.26 million, as shown in Figure 1.

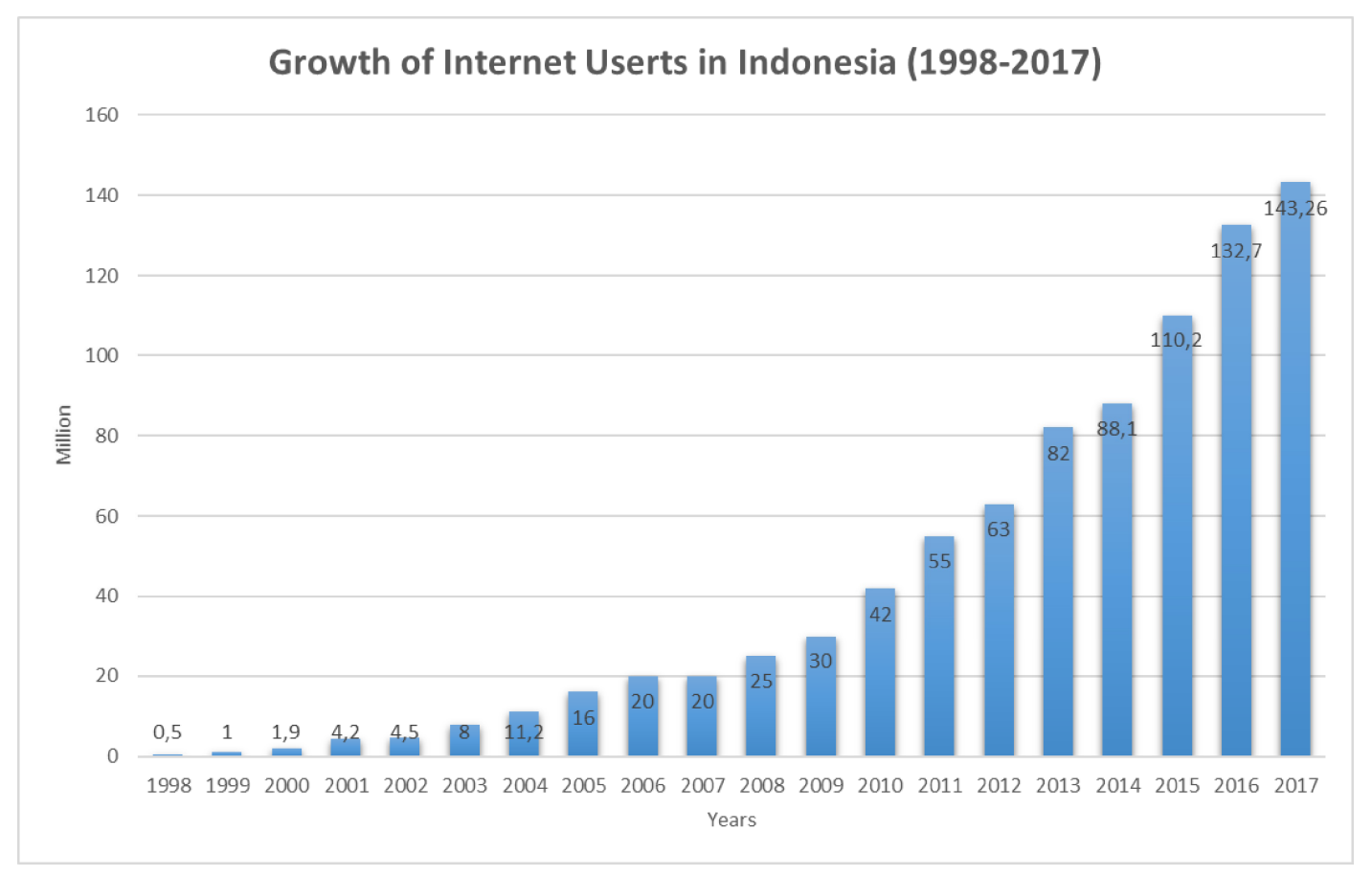

Figure 1. Growth of Internet Users in Indonesia (1998-2017)

Source: (APJII, 2017)

This significant growth is supported by data showing that the majority (93.9\%) of Indonesians access the internet via smartphones, thus driving the increase in internet users in Indonesia (APJII, 2018). Therefore, marketers use that way to advertise on online media is by implementing mobile advertising or placing ads on devices that have high mobility and are often carried by consumers (Bart, Stephen, $\&$ Sarvary, 2014). There are several ways marketers can take to implement mobile advertising; among them are pop-up advertising, mobile online banners, mobile display advertising, mobile advergames, location-based advertising, and others.
One form of advertising that is popular and made possible by the combination of the Internet and smartphones is location-based advertising (LBA). LBA is a marketing strategy using cellular devices such as smartphones to offer products to potential customers at the nearest sales or service location. In general, LBA refers to information controlled by marketers created where users access advertisements (Bruner \& Kumar, 2007). LBA aims to eliminate geographical barriers and information between consumers and market offerings by reaching buyers when they are near the advertiser's location. Even though such contextual advertising 
Jurnal Bisnis dan Manajemen, Volume 21, No. 2, September 2020, p. 88-99

seems comfortable, it can also be considered annoying. Some recipients will decide to ignore it because they see from a notification that appears from their cell phone and realizes it is only an advertisement (Pramodhana \& Sari, 2017).

The nature of the LBA that suddenly appears on the screen of a smartphone when a customer is somewhere might cause some consequences. On the other hand, the existence of LBA can make it easier for customers to get information about promotions from certain merchants somewhere; besides that LBA has the potential to disrupt customers' convenience because its appearance is not necessarily desired, so some customers consider it spam (Bruner \& Kumar, 2007). Similarly, Chowdhury, Parvin, Weitenberner, \& Becker (2006) stated that mobile advertising sometimes presents information that is confusing and disliked by the recipient of the ad, so the recipient considers it useless information. When consumers are confused and feel annoyed with advertising, consumers will react to the opposite of what the advertiser wants. Consumer perceptions of mobile advertising tend to be negative because certain formats that consumers consider are disturbing (Bittner \& Zondervan, 2015).

In a study of consumers in America, it was found that intrusiveness was the main cause that made advertising annoying (Logan, 2013). The intrusiveness perception arises because the presence of advertisements tends to force consumers to stop all activities they are doing in an online environment. This situation also raises negative emotions or consumer irritation (Lee, Kim, Lim, \&
Kim, 2015). Research conducted by Billore (2015) found that advertisements placed on LBA generate disturbing feelings that negatively impact consumer attitudes towards advertising and intention to buy. In this study, we try to determine the relationship between intrusiveness and irritation to purchase intentions.

\section{LITERATUR REVIEW}

\section{Mobile Advertising}

Advertising communication aims to reach the target audience, increase brand recall, and increase sales (Chowdhury et al., 2006). There are two factors for developing this strategy: (1) how the communication channels are used and (2) how the behavior of the channels used by the audience (Dholakia, 2004). Therefore, to get the attention of the target audience, advertisers need to choose the right media.

In general, mobile advertising is the transmission of advertisements via mobile devices (Yang, 2007). Cellular advertising refers to advertising messages via mobile devices such as cell phones (Haghirian \& Madlberger, 2005). Since mobile phones are highly personal devices that allow a person to be accessed virtually anywhere and anytime, mobile advertising needs to be more personal and can take different forms.

Globally, the high rate of cell phone penetration has resulted in increased use of mobile advertisements to market products and services. Mobile advertising is different from traditional media advertising. Among them are (a) interactive and (b) personal targets (Bauer, Reichardt, Barnes, 
Jurnal Bisnis dan Manajemen, Volume 21, No. 2, September 2020, p. 88-99

\& Neumann, 2005). Interactivity here means to provide the ability for users to "select and respond to" certain advertisements they like (Pavlou \& Stewart, 2000).

\section{Location-Based Advertising}

LBA is information that is controlled by marketers who are adjusted for the geographical position of the recipient and accepted on cellular communication devices (Bauer et al., 2005).

Based on the conceptual model of Aaron Gazley, Adam Hunt, and Lachlan Mclarent, LBA has elements that influence attitudes to purchase intentions (Gazley et al., 2015). There are six LBA elements: Message Type, Permission, Customization, Involvement, Intrusiveness, and Timing. In contrast, the LBA model of Ducoffe (1996) adds an element of Irritation in it (Tsang, Ho, \& Liang, 2004). Intrusiveness is the feeling of being disturbed or disturbed by consumers when doing an activity (Goodrich, Schiller, \& Galletta, 2015). At the same time, Irritation is consumer negative emotions expressed in the form of anger or irritation (Martí-Parreño, Aldás-Manzano, Currás-Pérez, \& Sánchez-García, 2013).

The researcher took only two elements under study, namely intrusiveness and irritation. The reason is that these two elements are the harmful elements of several components that have been studied before on consumer attitudes towards advertising, so this is what makes this research novelty.

\section{Attitude on Advertising}

Attitude toward advertising is defined as "a tendency to respond in a like or dislike behavior to an advertisement in a certain condition" (MacKenzie, Lutz, \& Belch, 1986). Attitude toward advertising is defined as "a tendency to respond in a like or dislike behavior to an advertisement in a certain condition" (MacKenzie \& Lutz, 1989). Concerning the world of the advertising industry, take an attitude towards the advertising viewpoint as a tool to see consumer behavior towards an advertisement (Greyser \& Bauer, 1966).

Whereas Bruner \& Kumar (2007) state that one's attitude towards location-based advertising is defined as one's general tendency towards commercial messages received on personal cellular communication devices and adjusted for one's geographical position. Some opinions may be that someone's attitude towards LBA is positive, and some are negative. Some consider it like a miracle and be happy, but on the other hand, it is also seen as pessimistic. Those who tend to be pessimistic about life are more likely to have negative attitudes about the LBA (Bruner \& Kumar, 2007). Those who tend to be pessimistic about life are more likely to have negative attitudes about LBA (Bruner \& Kumar, 2007).

The dimensions of attitude towards advertising used in this study are dimensions based on Ramaprasad (2001) and Brackett \& Carr (2001), which are as follows. First is credibility, namely, the clarity of the message content conveyed through the advertisements used. Second is informative, namely, 
Jurnal Bisnis dan Manajemen, Volume 21, No. 2, September 2020, p. 88-99

the clarity of product information provided through the advertisement used. Based on the description above, the following hypotheses are arranged:

H1: Intrusiveness has negative effects on consumer attitudes towards advertising.

H2: Irritation has negative effects on consumer attitudes towards advertising.

\section{Purchase Intention}

The intention to buy is the tendency of consumers to buy a brand or take action related to a purchase that is measured by the level of possibility that consumers make a purchase. It can be related to consumer behavior and their attitude in responding to product offerings. Kotler \& Keller (2016) define it as an essential key point for consumers while considering and evaluating certain products (Kusumasondjaja, 2016). The intention of purchase consumers can largely be influenced by their perceptions and also by attitudes not to avoid advertisements.
The purchase intention dimension used is a dimension based on (Gazley et al., 2015). Dimensions used to consist of a) the tendency of consumers to want to buy a product, b) consumer behavior as a primary preference for the product, and c. consumer behavior for always looking for information about the product of interest. Based on the description above, the following hypotheses are arranged:

H3: Consumer attitudes on Advertising have a positive effect on purchase intention

H4: Intrusiveness has a negative effect on purchase intention.

H5: Irritation has a negative effect on purchase intention.

The research model showing the relationship between all variables which have been discussed above is presented in Figure 2.

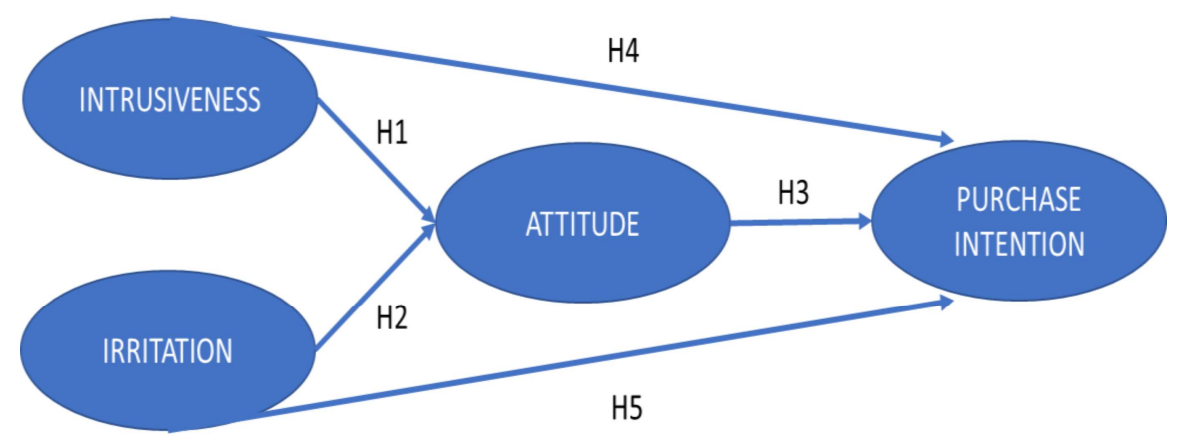

Figure 2. Research Model 
Jurnal Bisnis dan Manajemen, Volume 21, No. 2, September 2020, p. 88-99

\section{METHODS}

Based on the problem to be answered, this research can be categorized as explanatory research using survey research designs. This type of research aims to obtain an explanation of the relationship between intrusiveness, irritation, attitude, and purchase intention. The objects of this research are Irritation and Intrusiveness as independent variables, Attitudes towards Advertising as intervening variables, and purchase intention as the dependent variable (Y). The variables in this study are shown in Table 1.

The data collection process was carried out at Polytechnic Pos Indonesia Jln. Sariasih No. 54 Bandung, with students as respondents. The questionnaire was distributed to respondents using a self-administered survey approach. Screening questions are asked before the questionnaire is submitted to ensure compliance with the expected characteristics of the respondents and we used semantic differential scale with 7 point likert scale.

The sample for this study was 356 Politeknik Pos Indonesia students. Data were collected through an online questionnaire. In measuring the items representing the constructs shown in the research model and Table 1.

This study used path analysis with Cronbach's alpha for reliability and product-moment correlation for validity. Amos and SPSS version 23 was applied in analyzing the data.

Table. 1 Operationalization of Variables

\begin{tabular}{|c|c|c|}
\hline Construct & Definition of operational & Indicators \\
\hline Intrusiveness & $\begin{array}{l}\text { Intrusiveness is the feeling of being disturbed or } \\
\text { disturbed by consumers when doing an activity } \\
\text { (Goodrich et al., 2015) }\end{array}$ & $\begin{array}{l}\text { 1. The advert distracts me from the activity at hand } \\
\text { 2. The ad is distracting me from the action that is being } \\
\text { done } \\
\text { 3. The advertisement forces me to pay attention to its } \\
\text { message }\end{array}$ \\
\hline Irritation & $\begin{array}{l}\text { Negative consumer emotions expressed in the } \\
\text { form of anger or irritation } \\
\text { (Martí-Parreño et al., 2013) }\end{array}$ & $\begin{array}{l}\text { 1. These ads irritate me } \\
\text { 2. The advertisement made me angry }\end{array}$ \\
\hline $\begin{array}{c}\text { Attitude } \\
\text { toward } \\
\text { Advertising }\end{array}$ & $\begin{array}{l}\text { The tendency to respond in a like or dislike } \\
\text { behavior to an advertisement under certain } \\
\text { conditions } \\
\text { (MacKenzie et al., 1986) }\end{array}$ & $\begin{array}{l}\text { 1. Clarity of message content conveyed through } \\
\text { advertisements } \\
\text { 2. Clarity of product information gave through } \\
\text { advertisements } \\
\text { 3. My interest in the ad delivered }\end{array}$ \\
\hline $\begin{array}{l}\text { Purchase } \\
\text { Intention }\end{array}$ & $\begin{array}{l}\text { Individual tendency to make purchases on } \\
\text { advertised products } \\
\text { (Gazley et al., 2015) }\end{array}$ & $\begin{array}{l}\text { 1. The possibility that I purchased the advertised } \\
\text { product } \\
\text { 2. My belief in buying the advertised product } \\
\text { 3. If I am looking for a product and then I get a } \\
\text { message about that product, then I probably bought } \\
\text { the product advertised } \\
\text { 4. I might consider purchasing the advertised product } \\
\text { 5. My willingness to accept the advertised product }\end{array}$ \\
\hline
\end{tabular}


Jurnal Bisnis dan Manajemen, Volume 21, No. 2, September 2020, p. 88-99

\section{RESULTS AND DISCUSSION}

\section{Profile of Respondents}

The following table shows the demographic information of the respondents in this study.

Table 2. Demographic Information of Respondents

\begin{tabular}{llcc}
\hline \multicolumn{1}{c}{ Measure } & \multicolumn{1}{c}{ Items } & Frequency & Percent \\
\hline Gender & Female & 229 & $64,3 \%$ \\
Cellular Operator Used by & Telkomsel & 213 & $59,8 \%$ \\
Respondents & XL & 59 & $16,6 \%$ \\
& Tri & 42 & $11,8 \%$ \\
& Indosat & 33 & $9,2 \%$ \\
Frequency LBA Ad viewed & SmrtFren & 9 & $2,5 \%$ \\
by Respondents & $1-3$ times/day & 287 & $80,6 \%$ \\
& $4-6$ times/day & 54 & $15,2 \%$ \\
& $>6$ times/day & 15 & $4,2 \%$ \\
\hline
\end{tabular}

Source: Author's own

Female respondents have a dominant contribution, with 229 respondents or $64,3 \%$ of the total population. Male respondents contributed 127 individuals of the total individuals. So, it can be concluded that this study was dominated by female respondents. Some psychological studies show that individual behavior can be differentiated by sex. The results showed that women were more willing to adjust to organizational authority than men. In other words, a woman is considered more cooperative than men (Robbins, 2008). Based on this information, the behavior shown by a smartphone user in responding to LBA is influenced by gender. This factor guides user behavior in dealing with LBA messages.

Based on cellular operators used by respondents, $59.8 \%$ of respondents used Telkomsel cellular operators, followed by XL at $16.6 \%$, then Tri 42\%, Indosat 33\%, and SmartFren 9\%. Whereas, when viewed from the LBA frequency received, it can be concluded that the majority of respondents that are equal to $80.6 \%$, receive LBA messages on their smartphones in one day is 1-3 times. This can happen because respondents rarely move around and are in a long time in the same LBA coverage area or region, so there is no LBA message that is different.

\section{Intrusiveness}

Based on the results of data analysis on the Intrusiveness variable, the smallest average is that the LBA Receiver's Interference Level of the message delivered. It can be concluded that the average level of annoyance of respondents to LBA is relatively low. That is, it could be because the LBA is delivered using SMS media so that it relatively does not interfere with the activities of the respondents compared to other media, which generally require the concentration of respondents, such as games or web pages. Also, the respondents in this study were students whose majority of their time was spent on campus, so that the LBA exposure was not so obvious, considering that the LBA would only be sent if there were merchants 
Jurnal Bisnis dan Manajemen, Volume 21, No. 2, September 2020, p. 88-99

who worked with the provider and at the same time the respondent was in the exposure area.

While the average intrusiveness variable that has the greatest value is the level of response of respondents from the activity being carried out. It implies that the level of response of respondents to the LBA delivered is relatively low. Respondents tend not to be distracted by the work being done. It can happen because respondents are students who have limited time to open or respond to their smartphone while in class, so their responsiveness to LBA is relatively low, and they may only be able to read LBA messages after finishing lectures or during recess.

Likewise, the Level of Coercion implies that the level of compulsion of respondents to see LBA is low. Respondents tend not to be forced, or there is no compulsion for respondents to see or receive LBA messages on their smartphones. It could even be that the LBA message is what they are waiting for.

So, it can be concluded that the level of intrusiveness of respondents towards LBA messages tends is low. Respondents consider the LBA message is not disturbing that makes the respondent must divert his attention from the activity being carried out or forced to have to see the LBA message sent.

\section{Irritation}

The smallest average of irritation is the LBA recipient aggravation rate of the message delivered. It implies that the respondent was not annoyed by the LBA message he got. Likewise, about anger levels, respondents understood that the respondents' anger level towards LBA messages was low.

\section{Attitude}

For the attitude variable, the smallest average is the level of respondents' interest in the LBA message delivered is relatively low. This can happen because LBA messages are delivered via SMS, which is only in the form of texting (plain writing messages that have no additional animation or visualization that shows interactive images or audio that attracts attention), so they are less attractive. Besides that, there is no problem for respondents to understand the contents of the message and the information sent by the LBA message.

\section{Purchase Intention}

The smallest average for Purchase Intention is implied that the probability of the respondent buying the product offered at that time by the LBA message is relatively small. It means that the product or service offered by the LBA is not needed by the respondent so that the respondent ignores the message. It could also be because the message received is just the same product or service because of the low level of mobility of respondents who are only in the campus area and its surroundings. The frequency of respondents receiving LBA messages in one day classified as low, only 1- 3 times. It could be that the LBA message delivered is the same product or service every day, considering that the LBA will only be sent if a merchant is working with the provider. At the same time, the respondent is in the exposure area. 
Jurnal Bisnis dan Manajemen, Volume 21, No. 2, September 2020, p. 88-99

The highest average purchase intention is the probability that the respondent will buy the product offered at that time if the product is the product the respondent is looking for. It means that the likelihood of the respondent purchasing the work that appears in the LBA message being sought or needed by the respondent is relatively high.

\section{Path Analysis}

Table 3 below shows a summary of all the path coefficients of the causal relationship, showing the effects of each variable's direct causal and indirect causal effects.

Table 3. Result of Influence Based on Path Coefficient

\begin{tabular}{|c|c|c|c|c|}
\hline \multirow[b]{2}{*}{ Variable Influence } & \multirow[b]{2}{*}{$\begin{array}{c}\text { Path } \\
\text { Coefficient }\end{array}$} & \multicolumn{3}{|c|}{ Causal Influence } \\
\hline & & Direct & Indirect & $\begin{array}{c}\text { Shared } \\
\text { Influence }\end{array}$ \\
\hline $\mathrm{X} 1 \stackrel{---\rightarrow Y}{ }$ & 0,161 & 0,161 & - & - \\
\hline X2 ---- $\rightarrow Y$ & 0,195 & 0,195 & - & - \\
\hline X1 $----\rightarrow$ Z & $-0,176$ & $-0,176$ & $0,161 \times 0,462=0,074382$ & - \\
\hline X2 ---- $\rightarrow$ Z & 0,155 & 0,155 & $0,195 \times 0,462=0,09009$ & - \\
\hline $\mathrm{Y}----\rightarrow \mathrm{Z}$ & 0,462 & 0,462 & - & - \\
\hline $\mathrm{X} 1 \& \mathrm{X} 2 \stackrel{---}{\rightarrow} \mathrm{Y}$ & - & - & - & 0,081 \\
\hline $\mathrm{X} 1, \mathrm{X} 2 \& \mathrm{Y} \stackrel{---\rightarrow}{ } \mathrm{Z}$ & - & - & - & 0,253 \\
\hline$\varepsilon 1$ & 0,9 & 0,9 & - & - \\
\hline$\varepsilon 2$ & 0,728 & 0,728 & - & - \\
\hline
\end{tabular}

Source: Data Processed using SPSS AMOS 23, 2019

Based on table 3, it can be seen that Intrusiveness (X1) dan Irritation (X2) contribute positively and significantly to Attitude (Y). The intrusiveness (X1) contributes negatively and significantly to purchase intention $(Z)$. This means that the higher the Intrusiveness, the less the purchase intention. Irritation (X2) contributes positively and significantly to purchase intention $(\mathrm{Z})$, and the latest is attitude (Y) can significantly influence consumer purchase intention $(Z)$.
So, the overall contribution is given by each variable namely Intrusiveness (X1), Irritation (X2), Attitudes Against Advertisements (Y) has a significant impact on consumers' Purchase Intention (Z), even though the impact Intrusiveness (X1) variable is negative. Simultaneously with an orange line the overall structure model can be seen in Figure 3. 
Jurnal Bisnis dan Manajemen, Volume 21, No. 2, September 2020, p. 88-99

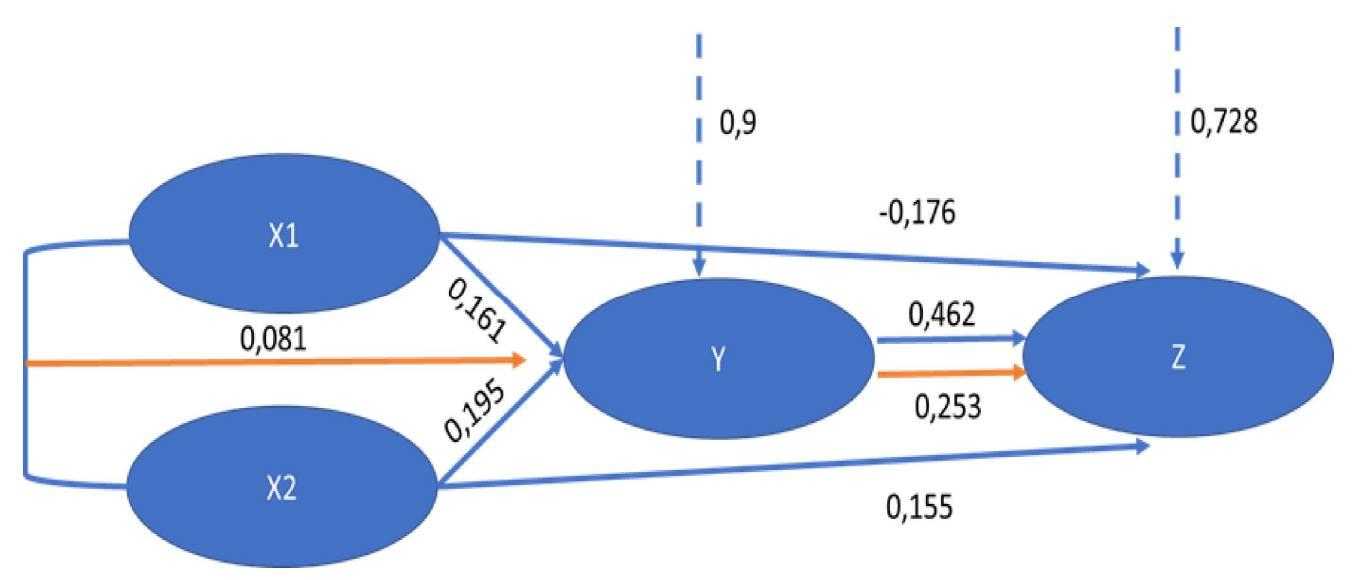

Figure 3. Overall Path Chart of Research Structure

Based on the model above, Intrusiveness (X1) and Irritation (X2) contribute to Attitude (Y) positively and significantly as well as Intrusiveness (X1) and Irritation (X2) through Attitude (Y) proved to contribute to Buying Interest $(\mathrm{Z})$ by $25.3 \%$ positively and significantly. After the simultaneous effect test, the following results are obtained as follows:

1. The Intrusiveness (X1) contributes positively and significantly to Attitude (Y). Based on the findings of this study, Intrusiveness contributed $0.1612 \times 100 \%=2.59 \%$. It shows that Intrusiveness can influence attitude significantly.

2. Irritation (X2) contributes positively and significantly to Attitude (Y). Based on the findings of this study, Irritation contributed $0.1952 \times 100 \%=3.06 \%$. It shows that Irritation can significantly influence attitudes.

3. The Intrusiveness (X1) contributes negatively and significantly to Buying Interest $(Z)$. The direct effect of Intrusiveness is $-0.1762 \times 100 \%$ $=-3.09 \%$. It shows that Intrusiveness affects
Purchase Interest negatively and significantly. It means that the higher the LBA intrusiveness, the less consumer interest in buying.

4. Irritation (X2) contributes positively and significantly to Buying Interest $(Z)$. The direct effect of Irritation is $0.1552 \times 100 \%=2.40 \%$. It shows that Irritation can significantly influence buying interest.

5. Attitude (Y) contributes positively and significantly to Buying Interest $(Z)$. The direct effect of attitude is $0.4622 \times 100 \%=21.34 \%$, and it is significant to Purchase Intention. It shows that attitudes can significantly influence consumer Purchase Intention.

Based on Figure 3 above, it can be concluded that all exogenous (free) variables have a significant effect on endogenous (bound) variables. However, some have a positive or negative impact.

\section{CONCLUSION}

This research attempts to determine the relationship between intrusiveness and irritation to purchase intentions. 
Jurnal Bisnis dan Manajemen, Volume 21, No. 2, September 2020, p. 88-99

After a series of statistical tests, both the outer and inner model, this research has met both the validity and reliability requirement. Thus, the model of this study is viable to be tested.

Intrusiveness caused by Location-based Advertising has a negative effect on consumer attitudes toward advertising. This hypothesis is rejected. Based on the results of data processing, it was found otherwise that Intrusiveness had a positive and significant effect on consumer attitudes toward advertising. This contrasts with the research conducted by (Pramodhana \& Sari, 2017), which states that Intrusiveness has a negative impact on advertising.

Irritation caused by Location-based Advertising has a negative effect on consumer attitudes toward advertising. This hypothesis is rejected. Based on the results of data processing it was found otherwise that Irritation had a positive and significant effect on consumer attitudes towards advertising. This result contrasts with the research conducted by (Kim \& Han, 2014; Martins, Costa, Oliveira, Gonçalves, \& Branco, 2019), which states that Intrusiveness has a negative impact on advertising. The attitude of consumers towards Location-based Advertising has a positive effect on the intention to buy the advertised product. This hypothesis is accepted. Based on the results of data processing, it was found that consumer attitudes had a positive and significant effect on purchase intention. This is in line with previous research conducted by (Pramodhana \& Sari, 2017), but in contrast to research conducted by (Kusumasondjaja, 2016) which states that consumer attitudes towards advertising have no effect on buying interest. Intrusiveness caused by Location-based Advertising has a negative effect on the intention to buy the advertised product. Hypothesis accepted. Based on the results of data processing, it was found that Intrusiveness had a negative and significant effect on purchase intention.

The irritation caused by Location-based Advertising has a negative effect on the purchase intention of the advertised product. The hypothesis is rejected. Based on the results of data processing, it was found that Irritation had a positive and significant effect on purchase intention.

\section{REFERENCES}

APJII. (2017). Penetrasi \& Perilaku Pengguna Internet Indonesia.

APJII. (2018). Infografis Penetrasi \& Perilaku Pengguna Internet Indonesia.

Bart, Y., Stephen, A. T., \& Sarvary, M. (2014). Which Products Are Best Suited to Mobile Advertising? A Field Study of Mobile Display Advertising Effects on Consumer Attitudes and Intentions. Journal of Marketing Research, LI(June 2014), 270-285.

Bauer, H. H., Reichardt, T., Barnes, S. J., \& Neumann, M. M. (2005). Driving Consumer Acceptance of Mobile Marketing : A Theoretical Framework and Empirical Study. Journal of Electronic Commerce Research, 6(3), 181-192.

Billore, A. (2015). Consumers' Attitude towards Permission Based Mobile Advertising. Pragyaan: Journal of Management, 13(7), 7-11.

Bittner, J. V, \& Zondervan, R. (2015). Computers in Human Behavior Motivating and AchievementEliciting Pop-Ups in Online Environments : A User Experience Perspective. Computers in Human Behavior, 50, 449-455. https://doi.org/10.1016/j.chb.2015.04.015

Brackett, L. K., \& Carr, B. N. (2001). Cyberspace Advertising vs Other Media : Consumer vs Mature Student Attitudes. Journal of Advertising Research, 41(5).

Bruner, G. C., \& Kumar, A. (2007). Attitude toward Location-based Advertising. Journal of Interactive Advertising, $\quad 7(2), \quad 3-15$. 
Jurnal Bisnis dan Manajemen, Volume 21, No. 2, September 2020, p. 88-99

https://doi.org/10.1080/15252019.2007.10722127

Chowdhury, H. K., Parvin, N., Weitenberner, C., \& Becker, M. (2006). Consumer Attitude toward Mobile Advertising in An Emerging Market: An Empirical Study. International Journal of Mobile Marketing, 1(2), 33-41.

Dholakia, R. R. (2004). Mobility and Markets: Emerging Outlines of M- commerce Mobility and Markets. Journal of Business Research, 57(12), 1391-1396. https://doi.org/10.1016/S01482963(02)00427-7

Ducoffe, R. H. (1996). Advertising value and advertising on the web. Journal of Advertising Research, (October), 21-35.

Gazley, A., Hunt, A., Mclaren, L., Gazley, A., Hunt, A., \& Mclaren, L. (2015). The Effects of LocationBases Service on Customer Purchase Intention at Point of Purchase. European Journal of Marketing, 49(9/10), 1686-1708. https://doi.org/10.1108/EJM-01-2014-0012

Goodrich, K., Schiller, S. Z., \& Galletta, D. (2015). Consumer Reactions to Intrusiveness of OnlineVideo Advertisements: Do Length, Informativeness, and Humor Help (or Hinder) Marketing Outcomes. Journal of Advertising Research, 55(1), 37-50. https://doi.org/10.2501/JAR-55-1-037-050

Greyser, S. A., \& Bauer, R. A. (1966). Americans and Advertising: Thirty Years of Public Opinion. Public Opinion Quarterly, 30(1), 69-78.

Haghirian, P., \& Madlberger, M. (2005). Consumer Attitude Toward Advertising via Mobile DevicesAn Empirical Investigation Among Austrian Users. European Conference on Information System (ECIS), $2005 . \quad$ Retrieved from $\mathrm{http} / / /$ aisel.aisnet.org/ecis2005

Kim, Y. J., \& Han, J. (2014). Why Smartphone Advertising Attracts Customers : A Model of Web Advertising, Flow, and Personalization. Computers in Human Behavior, 33, 256-269. https://doi.org/10.1016/j.chb.2014.01.015

Kotler, P., \& Keller, K. L. (2016). Marketing Management (15e Global). Edinburg: Pearson Education Limited.

Kusumasondjaja, S. (2016). Respon Konsumen pada Mobile Advergames: Intrusiveness dan Irritation. Jurnal Manajemen Teknologi, 15(3), 206-223. https://doi.org/10.12695/jmt.2016.15.3.1

Lee, E., Kim, Y. J., Lim, Y. S., \& Kim, M. (2015). Trait Reactance Moderates Facebook Users' Irritation With Brand Communication. Social Behaiour and Personality, 43(5), 829-844. https://doi.org/10.2224/sbp.2015.43.5.829

Logan, K. (2013). And Now A Word From Our Sponsor : Do Consumers Perceive Advertising On Traditional Television And Online Streaming Video Differently? Journal of Marketing Communications, 19(4), 258-276. https://doi.org/10.1080/13527266.2011.631568

MacKenzie, S. B., \& Lutz, R. J. (1989). An Empirical Examination of the Structural Antecedents of Attitude Toward the Ad in an Advertising Pretesting Context. Journal of Marketing, 53(2), 48-65.

https://doi.org/10.1177/002224298905300204

MacKenzie, S. B., Lutz, R. J., \& Belch, G. E. (1986). The Role of Attitude toward Ad as a Mediator of Advertising Effectiveness: A Test of Competing Explanations. Journal of Marketing Research, 23(2), 130-143.

Martí-Parreño, J., Aldás-Manzano, J., Currás-Pérez, R., \& Sánchez-García, I. (2013). Factors Contributing Brand Attitude in Advergames: Entertainment and Irritation. Journal of Brand Management, 20(5), 374-388. https://doi.org/10.1057/bm.2012.22

Martins, J., Costa, C., Oliveira, T., Gonçalves, R., \& Branco, F. (2019). How Smartphone Advertising In Fl Uences Consumers ' Purchase Intention. Journal of Business Research, 94, 378-387. https://doi.org/10.1016/j.jbusres.2017.12.047

Pavlou, P. A., \& Stewart, D. W. (2000). Measuring The Effects And Effectiveness Of Interactive Advertising: A Research Agenda. Journal of Interactive Advertising, 1(1), 62-78.

Pramodhana, A., \& Sari, P. K. (2017). Analysis of Location Based Advertising Towards Purchase Intention . Case Study: PT . Dunkin' Donuts. EProceeding of Management, 4(3), 2844-2850.

Ramaprasad, J. (2001). South Asian Students' Beliefs About and Attitude Toward Advertising. Journal of Current Issues and Research in Advertising, 23(1), 55-70.

https://doi.org/10.1080/10641734.2001.10505114

Robbins, S. (2008). Organizational Behavior $10^{\text {th }} \mathrm{Ed}$. Jakarta: Salemba Empat.

Tsang, M. M., Ho, S., \& Liang, T. (2004). Consumer Attitudes Toward Mobile Advertising: An Empirical Study. International Journal of Electronic Commerce, 8(3), 65-78.

Yang, K. C. C. (2007). Exploring Factors Affecting Consumer Intention to Use Mobile Advertising in Taiwan. Journal of International Consumer Marketing, 20(I), 33-49. https://doi.org/10.1300/J046v20n01 